\title{
INDUKSI KALUS LIMA KULTIVAR SELEDRI (Apium graveolens L.) DENGAN SUKROSA DAN BERBAGAI KONSENTRASI MALTOSA
}

\section{Embryogenic Callus Induction of Five Celery Cultivars (Apium graveolens L.) with Sucrose and Various Concentration of Maltose}

\author{
Adinda Humaira dan Suseno Amien* \\ Laboratorium Pemuliaan dan Teknologi Benih, Departemen Budidaya Pertanian, \\ Fakultas Pertanian Universitas Padjadjaran, Jalan Raya Jatinangor Km. 21 \\ Sumedang 45363
}

*Alamat Korespondensi: suseno@unpad.ac.id

\begin{abstract}
ABSTRAK
Penelitian ini bertujuan untuk mengetahui respon berbagai kultivar seledri terhadap induk sikalus dengan menggunakan sukrosa dan maltosa. Percobaan dilaksanakan dengan menggunakan Rancangan Acak Lengkap (RAL) pola faktorial yang terdiri atas dua faktor dan diulang tiga kali. Faktor pertama adalah kultivar seledri terdiri atas lima taraf yaitu Aroma, Bamby, Samantha, Sunda, Tall Utah. Faktor kedua adalah konsentrasi karbohidrat yang terdiri atas lima taraf yaitu sukrosa $20 \mathrm{~g} / \mathrm{L}$, maltosa $20 \mathrm{~g} / \mathrm{L}$ ), maltosa $30 \mathrm{~g} / \mathrm{L}$, maltosa $40 \mathrm{~g} / \mathrm{L}$, maltosa $60 \mathrm{~g} / \mathrm{L}$. Variabel yang diamati meliputi waktu awal kalus terbentuk, diameter kalus, warna kalus, tekstur kalus, kalus embriogenik, dan jumlah tunas pada tahap regenerasi. Hasil penelitian menunjukkan konsentrasi sukrosa $20 \mathrm{~g} / \mathrm{L}$ merupakan konsentrasi terbaik terhadap kecepatan muncul kalus pada kultivar Bamby. Sukrosa $20 \mathrm{~g} / \mathrm{L}$ memberikan pengaruh paling baik terhadap ukuran kalus pada kultivar Aroma. Maltosa $30 \mathrm{~g} / \mathrm{L} \mathrm{mampu}$ menginduksi kalus dari semua kultivar seledri yang digunakan. Kulvivar Samantha responsif terhadap pembentukan kalus di semua konsentrasi Maltosa yang digunakan.
\end{abstract}

Kata kunci: seledri, sukrosa, maltosa, kalus

\section{ABSTRACT}

Objective of this study was to find out the response of various celery cultivars for callus induction with the use of various maltose concentrations. The experiment was arranged in Completely Randomized Design (CRD) in factorial pattern consisted of two factors and replicated three times. The first factor was celery cultivars which consisted of five levels i.e. Aroma, Bamby, Samantha, Sunda, Tall Utah. The second factor was concentration of carbohydrate consisted of five levels i.e. sucrose $20 \mathrm{~g} / \mathrm{L}$, maltosa $20 \mathrm{~g} / \mathrm{L}$, maltosa $30 \mathrm{~g} / \mathrm{L}$, maltosa $40 \mathrm{~g} / \mathrm{L}$ ), maltose $60 \mathrm{~g} / \mathrm{L}$. The result showed that concentration of sucrose of $20 \mathrm{~g} / \mathrm{L}$ in Bamby cultivar gave the better effect to the speed up of callus emergence compared to the usage of maltose $20 \mathrm{~g} / \mathrm{L}$, maltose 30 $\mathrm{g} / \mathrm{L}$, maltose $40 \mathrm{~g} / \mathrm{L}$, and maltose $60 \mathrm{~g} / \mathrm{L}$. Sucrose of $20 \mathrm{~g} / \mathrm{L}$ on Aroma cultivars gave the best effect to callus size. Maltose with concentrations of $30 \mathrm{~g} / \mathrm{L}$ was capable to induce callus in all five celery cultivars. Cultivar Samantha responded on callus formation in all concentration of maltose.

Keywords: celery, sucrose, maltose,callus

\section{PENDAHULUAN}

\section{Seledri (Apium graveolens L.)} merupakan salah satu komoditas tanaman sayuran dari suku umbeliferae yang banyak digunakan sebagai penyedap makanan dan juga berkhasiat sebagai obat di Indonesia. Seledri banyak mengandung senyawa kimia seperti asparigina, glutamine, kolin dan vitamin A, C dan B (Rahma, 2008) serta mengandung glikosidaglikosida flavon, isoflavon, dan mengandung minyak atsiri (Nitihapsari, 2010). Daun seledri juga dapat menambah kandungan antioksidan pada bahan kosmetika (Rusdiana et al., 2007). Pemuliaan tanaman seledri terkendala oleh 
terbatasnya jumlah dan sumber bibit serta tingginya kontaminasi patogen yang terbawa bibit. Perbanyakan seledri dapat dilakukan menggunakan biji maupun anakan. Perbanyakan melalui anakan menghasilkan jumlah bibit yang rendah dengan umur bibit yang beragam. Perbanyakan seledri dengan biji mempunyai beberapa kelemahan, yaitu perkecambahannya lambat, tidak seragam, ukuran biji dan kecambah yang kecil menyebabkan kerentanan terhadap perubahan lingkungan mikro (Orton, 1984). Permasalahan tersebut dapat diatasi dengan teknologi kultur jaringan. Selain dapat digunakan untuk perbanyakan tanaman, teknologi kultur jaringan dapat digunakan untuk program pemuliaan in vitro berbasis kalus. Kalus merupakan bahan dasar untuk mempelajari bioteknologi tanaman, termasuk pengembangan berbagai jenis regenerasi dan proses embryogenesis (Ikeuchi et al., 2013; Osman et al., 2013). Regenerasi kalus melalui organogenesis menghasilkan massa sel yang memiliki bentuk globuler dan meristematik, dapat berkembang menjadi primordial akar dan tunas yang bersifat unipolar, sedangkan regenerasi melalui embriogenesis somatik mudah diregenerasikan menjadi embrio bipolar yang mempunyai dua kutub yang langsung sebagai bakal tunas dan akar (Sari et al., 2014).
Faktor yang mempengaruhi pertumbuhan kalus antara lain adalah tanaman, genotip, asal tanaman, eksplan dan media. Selain itu, yang mempengaruhi pertumbuhan eksplan menjadi kalus adalah jenis dan konsentrasi karbohidrat. Beberapa sumber karbohidrat yang biasa digunakan adalah glukosa, sukrosa, fruktosa, maltosa dan amilum. Sarkar and Roy (2015), menambahkan jenis sumber karbohidrat ke dalam media Murashige dan Skoog (1962) dengan konsentrasi 3\%. Efek terbaik pada tanaman Glycyrrhiza glabra L. terdapat pada pemberian maltosa. Maltosa dapat menjaga kestabilan osmosis pada media kultur (Priyantini dan Basunanda, 2013). Medium yang mengandung maltosa sebagai sumber karbon dapat melindungi kalus dari browning dan potensi tekanan osmotik (Darachai et al., 2010). Penelitian ini bertujuan untuk mengetahui respon berbagai kultivar seledri terhadap induksi kalus dengan menggunakan maltosa

\section{METODE PENELITIAN}

Penelitian ini dilaksanakan di Laboratorium Teknologi Kultur Jaringan Fakultas Pertanian Universitas Padjadjaran. Bahan Tanam yang digunakan untuk induksi kalus diambil dari beberapa lahan pertanian di Jawa Barat. Kultivar Aroma, Samantha dan Sunda diambil dari wilayah pertanian sayuran 
Desa Ciherang, Kecamatan Cipanas, Cianjur. Kultivar Bamby diambil dari wilayah pertanian seledri Desa Lebakmuncang, Kecamatan Ciwidey, Bandung. Kultivar Tall Utah diambil dari wilayah pertanian sayuran Desa Pagerwangi, Kecamatan Ciwidey, Bandung Barat. Tanaman disterilisasi menggunakan deterjen, aquades, fungisida, bakterisida, $\mathrm{HgCl}_{2} 1 \%, \mathrm{NaClO} 1 \%$. Media yang digunakan dalam kultur eksplan adalah media dasar WPM (Woody Plant Medium) (Lloyd dan McCown, 1980). Eksplan yang digunakan berupa potongan daun seledri berukuran 1x1 cm. Media dan Zat Pengatur Tumbuh (ZPT) yang digunakan pada tahap induksi kalus yaitu media WPM dengan ZPT 2,4-D 1 ppm dan Benzyl Adenin 1 ppm. Setelah itu dilanjutkan dengan sub-kultur pada media tahap perkembangan kalus embriogenik dengan media WPM yang mengandung ZPT 2,4 D 0,5 ppm dan kinetin 1 ppm. Pada tahap akhir kalus yang sudah berkembang dipindahkan ke media regenerasi yaitu media WPM menggunakan ZPT BA 1,5 ppm dan IAA 0,15 ppm. Setiap media ditambahkan maltosa dalam lima taraf. Eksplan daun yang sudah disterilisasi kemudian ditanam kedalam media kultur. Penanaman eksplan daun dilakukan secara aseptik dengan menggunakan pinset dan pisau yang sudah disterilkan pada media yang sudah disiapkan. Kultur diinkubasikan selama 10 minggu pada ruangan dengan kisaran suhu $20-30^{\circ} \mathrm{C}$ dan kelembaban rata- rata $70 \%$.

Penelitian menggunakan metode eksperimen, dengan rancangan yang digunakan adalah Rancangan Acak Lengkap pola faktorial yang terdiri dua faktor. Faktor pertama adalah kultivar seledri yang terdiri dari lima taraf yaitu Aroma, Bamby, Samantha, Sunda, Tall Utah. Faktor kedua adalah konsentrasi karbohidrat yang terdiri dari lima taraf yaitu c0 (Kontrol : Sukrosa 20 g/l), c1 (Maltosa $20 \mathrm{~g} / \mathrm{l}$ ), c2 (Maltosa $30 \mathrm{~g} / \mathrm{l}$ ), c3 (Maltosa $40 \mathrm{~g} / \mathrm{l}$ ), c4 (Maltosa $60 \mathrm{~g} / \mathrm{l}$ ). Dengan demikian didapat 25 kombinasi perlakuan dan masing-masing perlakuan diulang tiga kali. Setiap perlakuan dibuat tiga botol. Tiap botol perlakuan berisi 1 eksplan. Pengamatan utama yang diamati selama percobaan, yaitu 10 minggu setelah tanam (hst) terdiri atas Waktu Awal Kalus Terbentuk (HST), Diameter Kalus Terbentuk (mm), Warna Kalus, Tekstur Kalus, Kalus Embriogenik, Jumlah tunas pada tahap regenerasi.

Data yang diperoleh akan diuji $\mathrm{F}$ $(p=0,05)$ dan apabila terdapat perbedaan yang nyata dilanjutkan dengan uji DMRT (Duncan's Multiple Range Test) pada taraf $p=5 \%$.

\section{HASIL DAN PEMBAHASAN}

Kalus terbentuk ditandai dengan terjadinya penebalan eksplan pada bagian 
yang terdapat perlukaan. Kombinasi varietas, kandungan unsur dalam media dan zat pengatur tumbuh yang berbeda dapat mempengaruhi kecepatan pembentukkan kalus. Hasil analisis data dari pengamatan seluruh karakter utama pada Tabel 1 menunjukkan bahwa terdapat interaksi antara kultivar seledri dengan penggunaan maltosa.

Analisis varians pada pengaruh konsentrasi maltosa dan kultivar terhadap kecepatan muncul kalus seledri menunjukkan adanya interaksi. Tabel 2, waktu pembentukkan kalus antar kultivar berbeda-beda meskipun dalam perlakuan yang sama. Selain perbedaan kultivar dan kandungan media, konsentrasi karbohidrat mempengaruhi pembentukkan kalus.

Pada Tabel 2 beberapa kultivar menunjukkan nilai nol, tidak ada respon pembentukkan kalus sama sekali. Hal ini diduga karena kematian sel pada eksplan. Pada Tabel 2 terlihat waktu muncul kalus eksplan daun seledri yang paling cepat terdapat pada kombinasi perlakuan kultivar Bamby dengan media kontrol (WPM+20g/L sukrosa) sedangkan, kombinasi perlakuan yang membutuhkan waktu paling lama untuk pembentukkan kalus adalah kultivar Samantha dengan media (WPM+60g/ L Maltosa).

Tabel 1. Nilai Uji-F pada karakter pengamatan utama

\begin{tabular}{ccrrcc}
\hline & $\begin{array}{c}\text { Waktu muncul } \\
\text { Kalus (HST) }\end{array}$ & $\begin{array}{c}\text { Diameter } \\
\text { Kalus (I) }\end{array}$ & $\begin{array}{c}\text { Diameter } \\
\text { Kalus(II) }\end{array}$ & Warna Kalus & F tabel 5\% \\
\hline Kultivar(A) & $128,60^{\mathrm{s}}$ & $87,19^{\mathrm{s}}$ & $128,60^{\mathrm{s}}$ & $286,70^{\mathrm{s}}$ & 2,56 \\
Maltosa(C) & $196,25^{\mathrm{s}}$ & $149,77^{\mathrm{s}}$ & $196,25^{\mathrm{s}}$ & $174,92^{\mathrm{s}}$ & 2,56 \\
AXC & $52,63^{\mathrm{s}}$ & $39,27^{\mathrm{s}}$ & $52,63^{\mathrm{s}}$ & $67,83^{\mathrm{s}}$ & 1,85 \\
\hline
\end{tabular}

Keterangan : $\mathrm{s}=$ Berbeda nyata pada $p=5 \%$; HST $=$ hari setelah tanam

Tabel 2. Waktu kalus muncul lima kultivar seledri dalam berbagai konsentrasi maltosa (HST)

\begin{tabular}{|c|c|c|c|c|c|c|c|c|c|c|}
\hline \multirow[t]{2}{*}{ Kultivar } & \multicolumn{10}{|c|}{ Konsentrasi Maltosa } \\
\hline & $\mathrm{c}_{0}$ & & $\mathrm{c}_{1}$ & & $\mathrm{c}_{2}$ & & $\mathrm{c}_{3}$ & & $\mathrm{c}_{4}$ & \\
\hline Aroma & $\begin{array}{c}19,00 \\
\mathrm{C}\end{array}$ & $\mathrm{b}$ & $\begin{array}{c}0,00 \\
\text { A }\end{array}$ & $\mathrm{a}$ & $\begin{array}{c}25,00 \\
\text { BC }\end{array}$ & $\mathrm{b}$ & $\begin{array}{c}0,00 \\
\text { A }\end{array}$ & $\mathrm{a}$ & $\begin{array}{c}27,00 \\
\text { B }\end{array}$ & $\mathrm{b}$ \\
\hline Bamby & $\begin{array}{c}12,00 \\
\text { B }\end{array}$ & $\mathrm{b}$ & $\begin{array}{c}15,00 \\
\text { B }\end{array}$ & $\mathrm{c}$ & $\begin{array}{c}14,00 \\
\text { A }\end{array}$ & bc & $\begin{array}{c}16,00 \\
\text { B }\end{array}$ & $\mathrm{c}$ & $\begin{array}{c}0,00 \\
\mathrm{~A}\end{array}$ & $\mathrm{a}$ \\
\hline Samantha & $\begin{array}{c}18,00 \\
\mathrm{C}\end{array}$ & $\mathrm{a}$ & $\begin{array}{c}22,00 \\
\mathrm{C}\end{array}$ & $a b$ & $\begin{array}{c}17,00 \\
\mathrm{AB}\end{array}$ & $\mathrm{a}$ & $\begin{array}{c}25,00 \\
\mathrm{C}\end{array}$ & $\mathrm{b}$ & $\begin{array}{c}38,00 \\
\mathrm{C}\end{array}$ & $\mathrm{c}$ \\
\hline Sunda & $\begin{array}{c}23,00 \\
\mathrm{D}\end{array}$ & $\mathrm{b}$ & $\begin{array}{c}0,00 \\
\text { A }\end{array}$ & $\mathrm{a}$ & $\begin{array}{c}28,00 \\
\mathrm{C}\end{array}$ & $\mathrm{c}$ & $\begin{array}{c}0,00 \\
\text { A }\end{array}$ & $\mathrm{a}$ & $\begin{array}{c}0,00 \\
\mathrm{~A}\end{array}$ & $\mathrm{a}$ \\
\hline Tall Utah & $\begin{array}{c}0,00 \\
\mathrm{~A}\end{array}$ & $\mathrm{a}$ & $\begin{array}{c}0,00 \\
\text { A }\end{array}$ & $\mathrm{a}$ & $\begin{array}{c}18,00 \\
\mathrm{AB}\end{array}$ & $b$ & $\begin{array}{c}0,00 \\
\text { A }\end{array}$ & A & $\begin{array}{c}0,00 \\
\text { A }\end{array}$ & $\mathrm{a}$ \\
\hline
\end{tabular}

Keteranga: Nilai yang diikuti dengan huruf kecil yang sama pada baris yang sama, dan huruf besar yang sama pada kolom yang sama, dinyatakan tidak berbeda nyata menurut uji DMRT pada taraf $p=5 \%$. $\mathrm{c}_{0}$ (Kontrol : Sukrosa $20 \mathrm{~g} / \mathrm{l}$ ), $\mathrm{c}_{1}$ (Maltosa $\left.20 \mathrm{~g} / \mathrm{l}\right), \mathrm{c}_{2}$ (Maltosa $30 \mathrm{~g} / \mathrm{l}$ ), $\mathrm{c}_{3}$ (Maltosa $40 \mathrm{~g} / \mathrm{l}$ ), $\mathrm{c}_{4}$ (Maltosa $60 \mathrm{~g} / \mathrm{l}$ ). HST= Hari Setelah Tanam. 
Waktu muncul kalus menentukan efisiensi dan efektifitas dalam program pemuliaan tanaman. Semakin singkat waktu yang dibutuhkan untuk perolehan kalus maka semakin cepat perolehan hasil program pemuliaan.

Diameter kalus atau ukuran kalus yang terbentuk merupakan salah satu indikator adanya pertumbuhan dalam proses induksi kalus. Pengamatan diameter kalus dilakukan menggunakan skala clay models. Pengamatan diameter kalus pada tahap induksi kalus dilakukan selama 8 minggu setelah tanam pada media perlakuan. Pada Tabel 1 terlihat bahwa interaksi antara perlakuan kultivar serta konsentrasi maltosa pada media terhadap diameter kalus yang terbentuk menunjukkan perbedaan yang signifikan. Pada Tabel 3, diameter kalus terbesar diperoleh pada kombinasi perlakuan seledri kultivar Aroma dengan media kontrol yaitu WPM+20 g/L sukrosa. Pada beberapa kultivar terlihat tidak ada respon pembentukan kalus sama sekali yaitu pada perlakuan kultivar Aroma konsentrasi maltosa 20g/L, $40 \mathrm{~g} / \mathrm{L}$, Bamby (maltosa 60g/L), Sunda (maltosa 20 g/L, 40 g/L, 60 g/L, dan Tall Utah (sukrosa $20 \mathrm{~g} / \mathrm{L}$, maltosa $20 \mathrm{~g} / \mathrm{L}, 40 \mathrm{~g} / \mathrm{L}$, dan $60 \mathrm{~g} / \mathrm{L}$ ) yang menunjukkan nilai nol. Hal ini diduga karena ketidakcocokkan kultivar terhadap media sehingga tidak memberikan respon pembentukkan kalus sama sekali. Tidak terbentuknya kalus juga diduga akibat kematian sel eksplan. Diameter kalus yang kecil diduga karena konsentrasi maltosa untuk menginduksi pembentukkan kalus tidak cukup optimal pada setiap kultivar sehingga memberikan hasil yang kecil. Hal ini sejalan dengan penelitian Ningsih et al. (2016) pada induksi kalus tiga genotipe tomat, beragamnya ukuran kalus yang dihasilkan dan efisiensi pembentukkan kalus pada media yang digunakan menunjukkan bahwa genotipe yang berbeda mungkin saja membutuhkan media yang berbeda.

Setelah eksplan dipelihara selama 8 minggu di medium induksi kalus. Eksplan kemudian dipindahkan ke media perkembangan kalus embriogenik. Pada tahap ini beriringan dengan proliferasi kalus embriogenik, diamati diameter kalus untuk melihat respon perkembangan ukuran pada setiap perlakuan setelah eksplan dipindahkan pada media perkembangan kalus embriogenik.

Interaksi antara perlakuan kultivar serta konsentrasi maltosa pada media terhadap diameter kalus yang terbentuk menunjukkan perbedaan yang signifikan. Hasil uji pada tahap perkembangan kalus embriogenik menghasilkan interaksi yang sama dengan tahap induksi kalus. Dilihat dari Gambar 1, nilai rata-rata tiap 
p-ISSN: 1410-0029; e-ISSN2549-6786

Agrin Vol. 22, No. 1, April 2018

perlakuan dapat dilihat bahwa ukuran kalus dari tahap induksi kalus ke tahap perkembangan kalus embriogenik terdapat perkembangan ukuran.

Beberapa perlakuan yang mengalami perkembangan adalah kultivar Aroma (sukrosa $20 \mathrm{~g} / \mathrm{L}$, maltosa $30 \mathrm{~g} / \mathrm{L}$ ), Bamby (sukrosa $20 \mathrm{~g} / \mathrm{L}$, maltosa $20 \mathrm{~g} / \mathrm{L}, 30 \mathrm{~g} / \mathrm{L}$, $40 \mathrm{~g} / \mathrm{L}$ ), Samantha (sukrosa $20 \mathrm{~g} / \mathrm{L}$, maltosa $30 \mathrm{~g} / \mathrm{L}, 40 \mathrm{~g} / \mathrm{L}, 60 \mathrm{~g} / \mathrm{L})$ dan Tall Utah (maltosa $30 \mathrm{~g} / \mathrm{L}$ ).

Tabel 3. Diameter kalus lima kultivar seledri dalam berbagai konsentrasi maltosa

\begin{tabular}{cccccc}
\hline \multirow{2}{*}{ Kultivar } & \multicolumn{5}{c}{ Konsentrasi Maltosa } \\
\cline { 2 - 6 } & $\mathrm{c}_{0}$ & $\mathrm{c}_{1}$ & $\mathrm{c}_{2}$ & $\mathrm{c}_{3}$ & $\mathrm{c}_{4}$ \\
\hline Aroma & $9,33 \mathrm{c}$ & $0,00 \mathrm{a}$ & $5,33 \mathrm{~b}$ & $0,00 \mathrm{a}$ & $6,66 \mathrm{~b}$ \\
& $\mathrm{D}$ & $\mathrm{A}$ & $\mathrm{BC}$ & $\mathrm{A}$ & $\mathrm{C}$ \\
Bamby & $7,66 \mathrm{c}$ & $4,67 \mathrm{~b}$ & $7,00 \mathrm{c}$ & $3,66 \mathrm{~b}$ & $0,00 \mathrm{a}$ \\
& $\mathrm{C}$ & $\mathrm{C}$ & $\mathrm{BC}$ & $\mathrm{C}$ & $\mathrm{A}$ \\
Samantha & $4,00 \mathrm{~b}$ & $2,00 \mathrm{a}$ & $4,67 \mathrm{~b}$ & $2,33 \mathrm{a}$ & $4,00 \mathrm{~b}$ \\
& $\mathrm{~B}$ & $\mathrm{~B}$ & $\mathrm{AB}$ & $\mathrm{B}$ & $\mathrm{B}$ \\
Sunda & $5,00 \mathrm{c}$ & $0,00 \mathrm{a}$ & $2,67 \mathrm{~b}$ & $0,00 \mathrm{a}$ & $0,00 \mathrm{a}$ \\
& $\mathrm{B}$ & $\mathrm{A}$ & $\mathrm{AB}$ & $\mathrm{A}$ & $\mathrm{A}$ \\
Tall Utah & $0,00 \mathrm{a}$ & $0,00 \mathrm{a}$ & $7,33 \mathrm{~b}$ & $0,00 \mathrm{a}$ & $0,00 \mathrm{a}$ \\
& $\mathrm{A}$ & $\mathrm{A}$ & $\mathrm{C}$ & $\mathrm{A}$ & $\mathrm{A}$ \\
\hline
\end{tabular}

Keterangan: Nilai rata-rata yang diikuti dengan huruf kecil yang sama pada baris yang sama, dan huruf besar yang sama pada kolom yang sama, dinyatakan tidak berbeda nyata menurut uji DMRT pada taraf $p=5 \%$. a a (Aroma), a (Bamby), a 3 (Samantha), a 4 (Sunda), a 5 (Tall Utah), $c_{0}$ (Kontrol : Sukrosa $20 \mathrm{~g} / \mathrm{l}$ ), $\mathrm{c}_{1}$ (Maltosa $20 \mathrm{~g} / \mathrm{l}$ ), $\mathrm{c}_{2}$ (Maltosa $30 \mathrm{~g} / \mathrm{l}$ ), $\mathrm{c}_{3}$ (Maltosa $40 \mathrm{~g} / \mathrm{l}$ ), $\mathrm{c}_{4}$ (Maltosa $60 \mathrm{~g} / \mathrm{l}$ ).

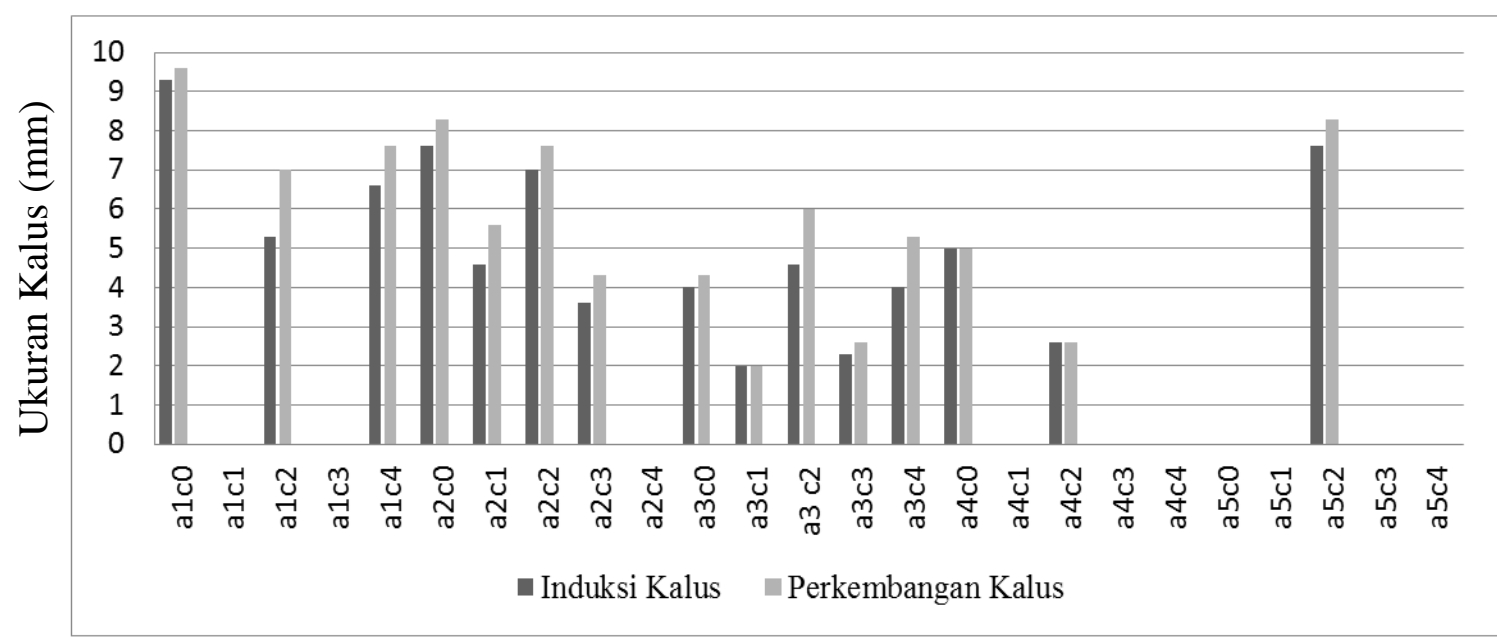

Gambar 1. Perkembangan ukuran kalus pada tahap induksi dan setelah subkultur ke media perkembangan kalus embriogenik. Keterangan: $a_{1}$ (Aroma), $a_{2}$ (Bamby), $a_{3}$ (Samantha), a $a_{4}$ (Sunda), a $a_{5}$ (Tall Utah), $\mathrm{c}_{0}$ (Kontrol : Sukrosa $20 \mathrm{~g} / \mathrm{l}$ ), $\mathrm{c}_{1}$ (Maltosa $20 \mathrm{~g} / \mathrm{l}$ ), $\mathrm{c}_{2}$ (Maltosa $30 \mathrm{~g} / \mathrm{l}$ ), $\mathrm{c}_{3}$ (Maltosa $40 \mathrm{~g} / \mathrm{l}$ ), $\mathrm{c}_{4}$ (Maltosa $60 \mathrm{~g} / \mathrm{l}$ ).

Sementara itu, perlakuan yang tidak mengalami perkembangan adalah kultivar
Samantha (maltosa $20 \mathrm{~g} / \mathrm{L}$ ), Sunda (sukrosa $20 \mathrm{~g} / \mathrm{L}$ ) dan Tall Utah (maltosa 
$30 \mathrm{~g} / \mathrm{L})$. Hal ini menunjukkan bahwa media perkembangan kalus embriogenik memberikan pengaruh terhadap perkembangan ukuran kalus setiap perlakuan tersebut. Namun pada beberapa kombinasi perlakuan, media perkembangan tidak sesuai untuk beberapa kultivar yang digunakan. Umumnya penggunaan 2,4-D dengan konsentrasi yang tinggi dapat menghambat embriogenesis. Namun, 2,4-D konsentrasi rendah yang digunakan dalam media pemeliharaan kalus dapat menstimulasi embriogenesis dan menjadi faktor pembantu dalam memelihara stabilitas kalus (William and Collin, 1976).

Pengamatan warna dan tekstur kalus dilakukan untuk menilai pertumbuhan kalus sebagai respon eksplan lima kultivar seledri terhadap media perlakuan yang diberikan. Karakter warna dan tekstur sangat penting untuk diperhatikan dalam proses embriogenesis somatik karena bisa menjadi indikator keberhasilan regenerasi. Kalus embriogenik ditandai dengan warna kalus putih kekuningan dan memiliki tekstur yang remah. Pengamatan dilakukan menggunakan skala warna kalus yaitu color chart The Royal Horticultural Society, sehingga memudahkan pengamatan. Skor rata-rata warna kalus yang mennjukkan warna putih dan kekuningan berada diantara skor 2 sampai dengan 3. Analisis menunjukkan skor ratarata warna antara 2 hingga 3 ada pada kultivar Aroma, Bamby dan Samantha. Pada proses pengamatan terdapat beberapa perlakuan yang memiliki tekstur kompak maupun remah. Skala warna yang terlampir merupakan hasil analisis skor warna berdasarkan color chart yang dihitung dengan analisis varians. Kultivar yang mampu menghasilkan kalus yang remah dari semua kalus yang dihasilkan adalah Aroma dan Bamby. Pada kultivar Samantha kalus yang remah hanya dihasilkan pada 2 jenis konsentrasi maltosa yaitu pada penggunaan maltosa $20 \mathrm{~g} / \mathrm{L}$ dan $60 \mathrm{~g} / \mathrm{L}$, sedangkan yang lainnya kompak.

\section{Kalus Embriogenik}

Kalus embriogenik ditandai dengan struktur kalus yang berwarna kekuningan dan remah (mudah dipisahkan). Kalus embriogenik mempunyai struktur friable, noduler dan berwarna putih atau kekuningan. Tekstur kalus yang remah dianggap baik karena memudahkan proses pemisahan menjadi sel-sel tunggal pada kultur serta akan meningkatkan aerasi oksigen antar sel ( Sari et al., 2014). Kalus embriogenik umumnya dapat diinduksi dengan menggunakan zat pengatur tumbuh auksin seperti 2,4 D dengan kombinasi dengan sitokinin (Yelnititis dan Komar, 2010). Embrio somatik yang terbentuk dari kalus biasanya diawali dengan proembrio yang tumbuh dari permukaan eksplan 
dengan suspensor yang terhubung pada kalus dan biasanya terjadi dalam bentuk gerombol. Keberhasilan embrio somatik akan tercapai apabila kalus atau sel yang digunakan bersifat embriogenik (Purnamaningsih, 2002). Kalus yang berpeluang embriogenik memiliki struktur yang bernodul dan remah ketika disentuh sementara kalus yang tidak berpeluang embriogenik, kalus bersifat lembek dan mengeluarkan cairan ketika disentuh (Wati, 2012). Dari hasil pengamatan dapat dilihat bahwa kombinasi perlakuan yang memenuhi kriteria sebagai kalus embriogenik adalah kombinasi perlakuan kultivar Aroma (sukrosa $20 \mathrm{~g} / \mathrm{L}$, maltosa 30g/L, $60 \mathrm{~g} / \mathrm{L}$ ), Bamby (sukrosa $20 \mathrm{~g} / \mathrm{L}$, maltosa 20 g/L, 30 g/L, 40 g/L), Samantha (maltosa $20 \mathrm{~g} / \mathrm{L}$ dan $40 \mathrm{~g} / \mathrm{L}$ ) karena memiliki skor rata-rata warna antara 2 hingga 3 serta memiliki tekstur kalus yang remah. Kalus yang berwarna putih atau kekuningan dengan tekstur remah merupakan kalus yang kompeten membentuk embrio somatik (Rusdianto dan Indrianto, 2012). Hal ini menunjukkan bahwa kombinasi perlakuan tersebut memiliki pengaruh terhadap pembentukkan kalus embiogenik. Namun, pada beberapa perlakuan tidak terdapat tanda pertumbuhan embrio. Kalus ditandai dengan tidak adanya perkembangan dan mengalami penggelapan warna.
Dari hasil pengamatan dapat disimpulkan bahwa pada kombinasi media dan kultivar terdapat ketidaksesuaian. Pada penelitian (Albert and Ezhova, 2013) gengen tertentu ternyata mengambil peran untuk mengatur aktivitas jaringan apikal tunas dan akar pada tanaman serta proses embriogenesis somatik. Proses morfogenetik dalam perkembangan organ tanaman yaitu pembelahan, pertumbuhan dan diferensisasi sel diatur oleh berbagai faktor endogen dan eksogen (Ezhova, 2003). Sel yang mempunyai kemampuan menjadi embriogenik sangat tergantung pada tingkat awal diferensisasi sel serta kondisi lingkungan yang mendukungnya terutama interaksi kandungan hormon endogen dengan konsentrasi zat pengatur tumbuh eksogen yang diberikan sehingga konsentrasi zat pengatur tumbuh di dalam sel dapat berubah. Perubahan konsentrasi tersebut merupakan triggering factor atau faktor pemicu yang dapat mempengaruhi ekspresi gen dalam menentukan embriogenesis somatik (Rusdianto dan Indrianto, 2012). Gambar 2 merupakan salah satu contoh kalus dari kultivar Aroma dengan perlakuan media menggunakan sukrosa $20 \mathrm{~g} / \mathrm{L} \quad$ yang memiliki nodul berwarna putih kekuningan (ditunjukkan dengan tanda panah) dan memiliki tekstur remah yang merupakan ciri kalus embriogenik. Semua kalus dari perlakuan yang memiliki tekstur remah 
membentuk nodul seperti pada Gambar 2, yang menandakan terbentuknya kalus embriogenik.

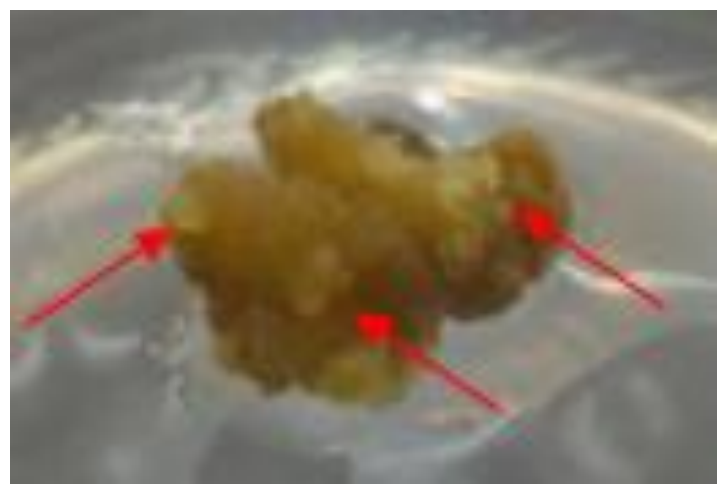

Gambar 2. Kalus yang memenuhi kriteria sebagai kalus embriogenik.

Pada umur 10 minggu setelah tanam, kalus yang terbentuk pada tahap induksi kalus dan perkembangan kalus embriogenik disubkultur ke media regenerasi yang diharapkan dapat menginduksi tunas. Kalus yang telah terinduksi, dipindahkan ke media regenerasi untuk diferensiasi tunas. Diferensiasi kalus menjadi tunas ditandai dengan terbentuknya spot-spot hijau pada kalus yang terjadi pada hari ke-4 dan 7 . Spot-spot hijau ini nantinya akan berdiferensiasi menjadi pucuk membutuhkan biasanya waktu 7- 10 hari pada media regenerasi. Setelah tunas terbentuk kemudian nantinya dipindahkan lagi ke medium bebas hormon. Namun pada penelitian ini media regenerasi belum mampu menginduksi tunas. Hal ini diduga akibat ketidakcocokan media dengan genotipe seledri yang digunakan untuk proses regenerasi. Terdapat dua faktor yang mempengaruhi keberhasilan proses regenerasi yaitu faktor internal dan faktor lingkungan. Genotipe tanaman, asal jaringan, tingkat perkembangan dan diferensiasi sel merupakan faktor internal. Komposisi media, suhu dan cahaya merupakan faktor lingkungan. Komposisi media yang baik untuk pertumbuhan tanaman jenis tertentu belum tentu baik untuk jenis tanaman lainnya, bahkan bagi jenis tanaman yang sama hanya varietas yang berbeda (Marveldani et al., 2007). Kalus embriogenik tidak bisa membentuk tunas karena masih ada pengaruh auksin dari media tahap induksi dan perkembangan kalus, waktu regenerasi yang tidak tepat atau jenis dan konsentrasi zat pengatur tumbuh untuk medium regenerasi yang tidak sesuai untuk proses regenerasi. Modifikasi kandungan media yang dibutuhkan untuk melihat pengaruh yang terjadi dalam proses regenerasi. Kalus pada medium regenerasi selama 2 minggu pengamatan setelah sub kultur menunjukkan pencokelatan. Pencokelatan dapat menurunkan kemampuan regenerasi in-vitro, toksisitas medium, dan kematian (Ningsih et al., 2016). Pencokelatan diduga disebabkan oleh kandungan auksin endogen dalam tanaman yang cukup tinggi, sehingga meningkatkan aktivitas etilen.

\section{KESIMPULAN}


1. Pemberian sukrosa 20 g/L pada Kultivar Bamby memberikan pengaruh paling baik pada karakter kecepatan waktu muncul kalus dan pemberian sukrosa 20 g/L pada kultivar Aroma memberikan pengaruh paling baik pada karakter ukuran kalus.

2. Pemberian maltosa $30 \mathrm{~g} / \mathrm{L}$ mampu menginduksi kalus pada kelima kultivar seledri.

3. Pemberian sukrosa $20 \mathrm{~g} / \mathrm{L}$ pada media dengan kultivar Aroma mampu menghasilkan kalus yang paling memenuhi kriteria sebagai kalus embriogenik.

\section{UCAPAN TERIMAKASIH}

Penulis mengucapkan terimakasih yang sebesar-besarnya kepada tim Laboratorium Kultur Jaringan Pemuliaan Tanaman Fakultas Pertanian Universitas Padjadjaran.

\section{DAFTAR PUSTAKA}

Albert, E.V. and T.A. Ezhova. 2013. Genetic regulation of plant shoot stem cells. Russian Journal of Genetics, 49 (2): 127 - 140.

Darachai, P., S. Chutipaijit, and K. Sompornpailin. 2012. Carbon Sources and Supporting Materials in Callus Induction Effects on Regeneration of Indica Rice (Oryza sativa L. Cv. RD6 and RD15). In Proc 8th Int Symp on Biocontrol and Biotech. pp. $266-272$.
Ezhova, T.A. 2003.Genetic control of totipotency of plant cells in an invitro culture. Russian Journal of Developmental Biology, 34(4): 197 204.

Ikeuchi, M., K.Sugimoto, and A. Iwase. 2013. Plant callus: mechanisms of induction and repression. Plant Cell, 25(9): 3159 - 3173.

Lloyd, G. and B. McCown. 1980. Commercially feasible micropropagation of mountain laurel Kalmia latifolia by use of shoot tip culture. Proc. Int.Conf. Plant Prop. Soc. pp. $421-427$.

Marveldani, M. Barmawi dan S.D Utomo. 2007. Regenerasi in vitro kedelai melalui organogenesis pada tiga konsentrasi benziladenin. Agrin, 11(2): $84-91$.

Murashige T, and F. Skoog. 1962. A revised medium for rapid growth and bioassay with tobacco tissue cultures. Physiol. Plant, 15: 473 - 497.

Ningsih, R., B.S. Purwoko, M. Syukur, dan I.S. Dewi. 2016. Induksi kalus dan regenerasi tiga genotipe tomat (Solanum lycopersicon L.) melalui kultur antera. J.Hort. Indonesia, 7(2): $75-82$.

Nitihapsari, Y. 2010. Efektivitas Ekstrak Seledri (Apium Graveolens) 50\% Dibandingkan Ketokonazol 2\% Terhadap Pertumbuhan Malassezia Sp. Pada Ketombe Galuh Yulieta. Artikel Ilmiah. Program Pendidikan Sarjana Kedokteran, Fakultas Kedokteran Universitas Diponegoro.

Osman, N.I, A. Awal, N.J.Sidik, and S.Abdullah. 2013. Callus induction and somatic embryogenesis from (Goji). Biotechnology, 12(1): 36 45.

Orton, T.J. 1984. Celery. In W.R. Sharp, D.A Evans, P.V. Ammirato and Y.Yamada (eds). Handbook of Plant 
Cell Culture.Volume II. Newyork: Macmillan Publishing Co.

Purnamaningsih, R. 2002. Regenerasi tanaman melalui embriogenesis somatik dan beberapa gen yang mengendalikannya. Buletin AgroBio. 5(2): 51-58.

Prayantini, D.C. dan P. Basunanda. 2013. Induksi haploid ganda pada padi Japonica (Oryza sativa L. ssp. japonica), Indica (Oryza sativa L. ssp. indica), dan Hibrida JaponicaX Indica. Ilmu Pertanian, 16(1): 14 29.

Rahma, J.Z. 2008.Validasi Metode Penentuan Kadar Apigenin Dalam Ekstrak Seledri Dengan Kromatografi Cair Kinerja Tinggi. Departemen Kimia Fakultas Matematika Dan Ilmu Pengetahuan Alam Institut Pertanian Bogor. Bogor.

Rusdianto dan A. Indrianto. 2012. Induksi kalus embriogenik pada wortel (Daucus Carota L.) menggunakan 2, 4-Dichlorophenoxyacetic Acid (2, 4D). Bionature, 13 (2): 136-140.

Rusdiana, T., I. Musfiroh dan A. Nawang. 2007. Formulasi gel antioksidan dari ekstrak seledri (Apium graveolens
L.) dengan menggunakan Aquapec HV.505. Makalah pada Kongres Ilmiah XV ISFI. Jakarta.

Sari, N., E. Suwarsi dan R. Sumadi. 2014. Optimasi jenis dan konsentrasi ZPT dalam induksi kalus embriogenik dan regenerasi menjadi planlet pada Carica pubescens. Biosaintifika, 6(1): 52-59.

Sarkar, M. and S.C. Roy. 2015. Influences of medium parameters on somatic embryogenesis from leaf explants of Glycyrrhiza glabra L. Indian J.Sci.Res., 10(1): 63 - 67.

Wati, R.P.D. 2012. Induksi Embriogenesis Somatik Organ Bunga Kakao (Theobroma Cacao L.) Secara In Vitro. Departemen Agronomi dan Hortikultura. Fakultas Pertanian. Institut Pertanian Bogor. Bogor.

Williams, L. and H. A. Collin. 1976. Embryogenesis and plantlet formation in tissue cultures of celery. Annals of Botany, 40(2): 325 - 332.

Yelnititis, and T.E. Komar. 2010. Upaya Induksi Kalus Embriogenik dari Potongan Daun Ramin. Bogor: Indonesia's Work Programme for 2008 ITTO CITES Project. 